Received: 29.04.2021.

doi: $10.46763 / J E S P T 211610035 \mathrm{C}$

udc: 028:37.091.322

37.016:003-028.31

Revised: 15. 05.2021.

Accepted: 25.05.2021

\title{
APPLICATION OF LITERARY ARTISTIC MODELS IN THE REALIZATION OF LITERATURE AND READING CONTENT
}

\author{
Ardita Ceka', Bujar Adili², Gzim Xhambazi ${ }^{3}$ \\ 'Faculty of Pedagogy, University of Tetova, Tetovo, North Macedonia \\ ardita.ceka@unite.edu.mk \\ ${ }^{2}$ Faculty of Educational Sciences, Goce Delchev University, Stip, North Macedonia \\ bujar.3141@student.ugd.edu.mk \\ ${ }^{3}$ Faculty of Pedagogy, University of Tetova, Tetovo, North Macedonia \\ gezim.xhambazi@unite.edu.mk
}

\begin{abstract}
Most of the acquisition of knowledge is realized through reading. The further successof the students will largely depend on the ways and the quality of mastering this activity. For this reason, in primary education classes, the mother tongue is represented by a wider range of classes. Part of itsprogram is the program content Reading and literature. The purpose of this paper is the application of literary and artistic models, as creative models, in the realization of literary and artistic contents. These contents are selected pieces from different literary genres, represented in the textbooks of the mother tongue subject. School readings are literary works of art, written in prose or poetry, which must be read in their entirety by all students, for a certain period of time. Reading them, among other things, helps the development of reading skills and critical thinking, increase of interest in reading, development of imagination etc. In this paper, some creative teaching models are described, which help facilitate and understand textbooks with artistic content.
\end{abstract}

Keywords: literary artistic models, reading, school reading.

\section{Introduction}

The teaching process must respect the principle that "Each learning unit represents something new and unknown for students", and depending on the content specifications, sometimes it is necessary to concretize and learn through illustrations, photos, dictionaries and encyclopedias. Texts in textbooks are excerpts from literary works and can serve the purpose to encourage the students to read the literary works as a whole, which, in primary and secondary education are known as reading material. Reading materials are literary worksof art that are represented by a number of titles for each class and have a characteristic character. Reading materials are made up of literary works that are processed during native language injury classes which students continue to read outside of school, as homework. Theissue of reading outside the classroom, specifically domestic reading material, is of great importance in learning from the mother tongue in primary schools given that the creation and cultivation of expressions for reading starts here. Grosman (2011) points out that students are primarily interested in those texts and their elements that are directly important to them and are understandable to them based on their own experience. In this way, we gradually encourage students to believe that an art story can be interesting for life, and not just as a subject of school conversation.

By etymological and semantic nature, reading material communicates with the readerin text form. Its basic goal is to successfully orient and enable children to read, understand and limit what is in the books. School-age children are psychologically characterized by greatcuriosity and intellectual turmoil, they are interested in a lot of things. Precisely, good books allow them to uncover some of the answers they expect, to find themselves in the book or compare their standpoints with the standpoints of the 
characters' in the book they are reading.Despite the fact that the printed book is an "obsolete medium", it also finds its place in the digitized environment because reading and literature are not extinct. Research confirms that young people prefer printed material over screen reading. Unfortunately, online reading habitsare reflected in their experience of paper editions (Loh \& Sun, 2019).

For the processing of texts and reading materials, in the curriculum, in most cases, twoteaching hours are provided, one for development and the other for interpretation and analysis. This short time prevents deepening in the ideological basis of the work (text), therefore the need for a more adequate preparation of students is presented to the teacher. At the processing of reading material, students should be notified in advance to the title of the work and they must have the book in front of them. In this class, the teacher usually introduces thestudents to the author of the work, with parts of the content of the work, asking some studentsto read more interesting parts of the work which the teacher has previously defined. In this class the teacher should orient the students in which parts of the literary work they should bemore careful in, and ask the students to keep a notebook while reading, for new and less known words, specific things that happened, different behaviors between people etc. The most important part, the integral reading of the work, continues as homework, so care must be taken not to overload the students, but to read the work to represent pleasure for the students. Thesetting of the lesson for interpretation and analysis of the reading should be done in accordance with the size and complexity of the work, as well as with the other engagements of the students in the reading period. Just as the teacher had to inform the students of the date of the development class, the same applies to the analysis and interpretation class, the teacher notifies the students in advance of the time when the reading analysis will be done, and it is even very reasonable to get the students' consent as well (Xhambazi, 2016). Depending on the literary genre of the work and its complexity, the class proceeds to the analysis of the content, discussion about the characters of the work, or expressive recitation of the literary work selected parts. Given that in our schools literary works with discriminatorycontent whether in terms of gender, race, nationality or religion are still being read, it is indispensable to discuss these behaviors and thoughts, while treating them as outdated and undesirable for today's life. Always showing students that we can not improve and change thepast, but from it we can understand how to live better, avoiding the above-mentioned negativephenomena which have been in a negative function of the development of human society.

\section{Importance of reading refinement}

Reading represents a skill that all students should acquire. The way and effort that students put in to learn this skill is different. Some authors are convinced that learning to read is closely related and depends on intelligence. If this ability is analyzed from a broader perspective it can be understood that more factors influence reading acquisition. Among the most important are the social circle, the physiological structure of the organism, especially the development of the ability to see, or more specifically among the most important factors on which depends the success of the acquisition of this ability we can count: organic and psychological factors and the social environment (McGuinness, 2006). As a consequence of technological development, electronically formatted texts are emerging that require a different approach to reading, as the way of interacting with the text changes (Duncan, McGeown, Griffiths, Stothard, \& Dobai, 2016).

Assuming that all children learn to read, there are some aspects that are directly related to the way and speed of acquisition of this skill. Just as children possess different individual characteristics, so does their ability to read. The question has always been asked, what should the child be provided with to master reading with as little effort as possible, because from this moment on further interest in reading depends. In the first contacts of the child with the book, the motivation and the right and adequate choice of texts are very important factors. Accuracy and speed of reading are directly related to the individual abilities of the child, therefore the correction of eventual errors in reading should be properly made, without causing the child a feeling of distrust in their abilities. At this age, some children also face dyslexia, i.e. they can not pronounce some letters correctly, thus the way their pronunciation will improve affects the further development of their reading ability. If this problem is more serious, then the help of people specialized in this field should be sought. Choosing the right texts and books for 
children to read should correspond to their interests and desires, they should be understandable and motivate children to read further.

The best time to start reading is thought to be at the age of six. Today, as a result of the development of telecommunication technologies and media, many children learn to read even before this age, and as a result of not caring for these children, this phenomenon "can inactivate them in further development of desires and interest in reading" (Xhambazi, 2016, p.69). Both children and adults read aloud or silently. Reading aloud is characteristic for childrenin the first cycle of primary education and depending on the possibilities and needs can be: individual reading, role reading and joint reading - in choir. To better understand the text, its content and message "reading aloud can be divided into logical reading and expressive reading" (Петковска, 2008, p. 125). Children learn these types of reading gradually in the following grades. For reading, Van Dyke \& Landi (2015) suggested that it is the interaction oflexical knowledge and interference arising from poor discrimination among lexical competitorsthat produces poor comprehension.

Reading silently, is a characteristic that comes into expression from the third grade onwards. Primary school children often practice silent reading for a number of reasons: they read to enjoy the literary work, they read to get acquainted with the literary work, to expand their knowledge, and so on. Silent reading is different from reading aloud according to the speed of reading, but this does not apply to elementary school students, because in these students there is no difference in the speed of reading aloud and reading silently. When children master reading, it continues to be silent, because in this way the speed of reading ishigher and for a shorter time more text is read. This speed depends on many factors, it is higher when reading a text which is previously known or more understandable, while the speedis lower when reading text with more complicated content or contains more new and unknown information. Reading as a skill for discovering thoughts through the written word, imposes the need for reduction of both words and sentences according to the age of the students. In the upper grades, children have acquired the ability to read, so longer sentences are used in textsdedicated to reading.

\section{Interactive approach to content processing from literature}

In the most successful realization of the contents from the artistic literature, in the process of the teaching work, different ways and means are used with which we are guided inthe achievement of certain goals. In teaching theory and practice, the criteria for the right choice of teaching methods represent a very serious problem. From the very voluminous literature that deals with this issue, we can briefly conclude that: When it comes to the application of teaching methods, we must always keep in mind the rules "never too much, butnot too little, and never too long with one method, but not so short that the whole intellectual and physical personality of the students is not engaged in the acquisition of knowledge, repetition and exercises of learning contents" (Zylfiu, 2001, p. 369). Many factors influence thedetermination of teaching methods, but as the most important is the teaching content, which depending on its specifics imposes the implementation of adequate methods.

In the process of processing teaching contents from literature, in order to developstudents' interests in reading and learning, all teaching methods are expressed. In this casewe will focus on the text method, as it comes into expression whenever the text/book is used.The text has always represented the main and most important source of knowledge, therefore working with text as a teaching method has always been the object of study of didactics and methodologies. Text as a source of knowledge has a great use in the teaching process, starting from the primer to university and academic texts. One of the essential tasksof the educational process is to train students for the correct and functional use of the text, with which text work has taken a key place in teaching methods, in all cycles and levels of education. In the process of teaching work during the acquisition of new knowledge, directly or indirectly when we use the text as a source of knowledge, then comes the work with text as a teaching method (Murati, 2007). Through this method, active links of action are establishedbetween the sources of knowledge (included in the text) and the students, which enables thestudents to use the text correctly. From a historical point of view, the text as the only source of knowledge and its excessive use, has often been criticized for having a negative attitude inthe excessive use of the text, because it has led to verbalism and formalism of knowledge. Today within the numerous sources of knowledge, 
the text continues to remain irreplaceable in teaching work, and any omission of it would be a great mistake.

In the learning process, the text also contributes to the organization of the lesson, because it enables normal work according to the possibilities of the students, differentiated learning, systematization of the lesson, deeper mental activity, etc. Viewed by its complexity,the text method is not in the function of learning only in the elaboration of new contents, it also finds application in the repetition and expansion of knowledge and is in the function of trainingstudents for permanent learning.

Reading and using the text, both in the learning process and outside it, as a method and as a process of daily learning activities, represents an important factor in terms of training students for learning, independent work and preparation for life. This social character of reading represents a special dimension of didactic goals, not only in the upliftment and permanent perfection of the individual, but also in the upliftment and cultural advancement.

\section{Creative models for the realization of program sets from literature}

The interpretation of literary artistic texts is a specific type of educational activity that is usually carried out with the help of a book. Various "activities and exercises can be developed in the textbooks, therefore some sub-models are applied in the literary-artistic models" (Stevanović, 2003, p. 351). In the following paragraphs we present some of the mostapplicable models.

Retelling according to the joint plan. In traditional teaching it is encountered as "text analysis". To affirm the creative actions of students, the plan should consist of several points.Based on the structure of the plan, students complete the reading of the work. In their notebooks the students mark the parts about which they show the most interest as well as thelesser known words and expressions. It is also preferred to note the time of activities, such as: the beginning of the reading of the work, the most appropriate time for reading, research andeventual discussions with other people about ambiguities in the text, etc. After the reading, other points of the plan are completed, such as: defining the idea, defining the motive, positive and negative characters, the author's message, etc. This sub-model gives positive results andserves as work for systematic continuation in this field. When the retelling according to the common plan is well practiced then it is passed to the individual story, which is usually realized in the lesson which is pre-determined by the teacher.

Ending the previously started conversation. This sub-model is applied during the lesson, when students are introduced to the work they need to read. The teacher, through short points, introduces the students to the content of the text. The moment he finds that the students' interest is high for the further course of the event, then he starts talking to the students. Some of them give opinions about the course of the event, or the end of the work. This greatly stimulates students' interest in reading the work as a whole. While reading outside of school, students are introduced to the true content of the conversation that began.

Shortening the conversation. The main elements/words or sentences are kept while the others are skipped/removed. The choice of words is essential which would provide the most adequate meaning of the content. (Example: remove some sentences from the given text, while the meaning remains the same). This sub-model is of particular importance when analyzing the contents of readings, as one lesson per work is temporarily insufficient. The taskof the teacher is to enable students to describe the content as briefly as possible, without changing its meaning.

Text expansion. This is the opposite activity of shortening the conversation. The giventext should be expanded with words and sentences. Sometimes, depending on the age of thestudents, new characters can be added to the text. This submodel is preferred for shorter texts, such as fairy tales and legends. Some of the textbooks do not have complete content. They consist of selected pieces from different works. In this case, expanding the text helps to develop students'imagination. The task of the teacher is to encourage the students and to direct their attention towards a further continuation of the event. In the case of literary works written in poetry, encouraging the writing of a verse or several verses would also represent the development and strengthening of students' self-confidence, self-actualization and motivation. 
Analogue talk. Based on the read text, students discuss the same content that they have read or heard before. Some of the literary and artistic works dedicated to school readingare also realized as animated films. Almost all preschool children get acquainted with these films before attending primary education. At the time of getting acquainted with the title of thework, conducting a conversation about the same would stimulate interest in reading. The teacher's task is to encourage students to read the work and to distinguish moments which may be different in the film and in the book. The experience of reading should be more pronounced than watching television. This model is not just about content that is realized in the lower cycle. The cinematographic industry has realized in feature films many of the events based on novels, which are part of the compulsory reading literature in primary and secondary education. These are crucial moments to orient students' interests in reading, through an analogy of film and literary work. Critical thinking is also expressed through analogous conversations, analyzing events from works with close content.

Literary artistic models are most often realized by analogy or by alternative. In many texts, especially in texts with artistic content, students encounter many events which are close to their life or experience. They want such texts because the need for expressing individual experiences in children is great. In the realization of contents for which students have prior knowledge, they should be able to express the knowledge they have read, watched on TV, orheard from the elders. In this case it is important that they understand the content by deepening the knowledge of what is now known to them.

Alternative learning is an exercise where the problem is posed in several possible ways, and students select the most appropriate. By analogy, the learning model can also be appliedwith the help of visual cues in the text.

\section{Conclusion}

The rapid technological development, that of electronic media in particular, enables the acquaintance of young people with different contents. Acceptance or rejection of these contents largely depends on the prior ability of students and young people to critically approach textbooks. School is the place where children learn to read, are trained in fluent reading, and are prepared for a critical approach to reading texts. The issue of (not)reading literary artistic contents has always been controversial. In the past, the strongest reason wasthe obstruction of students' access to books, as the number of books was smaller. Today reasons are different and more numerous. Students' interest in reading seems to be steadily declining, as a result of declining interest in reading. The realization of literary and artistic contents through the application of creative models, among other things, enables the increase of interest for reading. In this context, choosing the most appropriate and closest content to students' lives would help to show students' self-actualization and self-action, as special elements for stimulating optimism. This would help create the belief that personal development depends on selfcommitment. By developing and fostering optimism through the educational process, feelings of pessimism, inferiority, insecurity will be avoided, and at the same time emotional stability, desire and courage for reading and learning will be developed.

\section{References}

Duncan, L. G., McGeown, S. P., Griffiths, Y. M., Stothard, S. E., \& Dobai, A. (2016). Adolescent reading skill and engagement with digital and traditional literacies as predictors of reading comprehension. British Journal of Psychology, 107(2), 209-238. https://doi.org/10.1111/bjop.12134

Grosman, M. (2011). Readersand reading as interaction with literary texts. Primerjalna književnost, 34(2). https://ojs-gr.zrc-sazu.si/primerjalna knjizevnost/article/view/5457

Jashari, A., \& Ballhysa, A. (2005). Manual për të menduarit kritik, gjatë shkrimit dhe leximit. [Manual for critical thinking, while writing and reading] Elbasan.

Loh, C. E., \& Sun, B. (2019). "I'd Still Prefer to Read the Hard Copy": Adolescents' Print and Digital Reading 
Habits. Journal of Adolescent \& Adult Literacy, 62(6), 663-672. https://doi.org/10.1002/jaal.904

McGuinness, D. (2006). Language development and learning to read: The scientific study of how language development affects reading skill. Mit Press. https://doi.org/10.7551/mitpress/4113.001.0001

Murati, Xh. (2007). Organizimi I mësimit. [Organization of the lesson] Tetovo: Çabej

Petkovska, B. (2008). Metodika na kreativnata nastava po predmetot makedonski jazik vo nižite oddelenija na osnovnoto učilište. [Methodology of creative teaching of the subject Macedonian language in the lower grades of primary school], Skopje: Magor.

Stevanović, M. (2003). Modeli kreativne nastave. [Models of creative teaching]. Rijeka: Andromeda Retrieved from: https://www.bib.irb.hr/138527

Uljens, M., (2006). Didaktika shkollore. [School Didactics]. Skopje: Ars-Lamina.

Van Dyke, J., \& Landi, N. (2015). The developmentof reading comprehension skill:Processing and memory. In E. Bavin \& L. Naigles (Eds.), The Cambridge Handbook of Child Language (Cambridge Handbooks in Language and Linguistics, pp. 740-762). Cambridge: Cambridge University Press. https://doi. org/10.1017/CBO9781316095829.034

Xhambazi, G. (2016). Barazia gjinore në kontekstin e letërsisë artistike. Tetovë: Universiteti I Tetovës [Gender equality in the context of fiction]. Tetovo: University of Tetovo)

Zylfiu, N. (2001). Didaktika [Didactics]. Prishtinë: Universiteti I Prishtinës. 